\title{
REALTIME MOBILE QUEUE SYSTEM MULTI VENDOR
}

\author{
Usman Nurhasan ${ }^{1}$, Putra Prima Arhandi ${ }^{2}$, Muhammad Rizki O. ${ }^{3}$, Rafidah Putri H. ${ }^{4}$ \\ Program Studi Manajemen Informatika, Jurusan Teknologi Informasi, \\ Politeknik Negeri Malang \\ 1'usmannurhasan@gmail.com, ${ }^{2}$ putraprima@gmail.com, ${ }^{3}$ rizki.oktaviansyah@gmail.com, \\ ${ }^{4}$ rafiedah.putri@gmail.com
}

\begin{abstract}
Abstrak
Antrian merupakan fenomena yang tak terelakkan dan pasti ditemui pada setiap pelayanan publik. Dimana terlihat jelas bahwa antrian menimbulkan pemborosan waktu dan ketidaknyamanan bagi pelanggan seperti antrian yang panjang sehingga menyebabkan waktu tunggu yang lama. Oleh karena itu, maka dikembangkanlah teknologi berbasis mobile yang akan menggantikan sistem antrian yang ada, sehingga diharapkan dapat memberikan kepuasan kepada pelanggan dalam berbagai pelayanan publik. Selain itu, aplikasi ini diharapkan pula dapat mengorganisir sistem antrian berbagai pelayanan publik (multi vendor) sehingga lebih tertata, rapi dan mudah diakses.
\end{abstract}

Kata kunci : realtime, mobile, sistem antrian

\section{Pendahuluan}

Antrian merupakan kejadian yang dapat ditemui di berbagai tempat yang memberikan pelayanan kepada masyarakat diantaranya bank, rumah sakit, kantor pajak, loket stasiun, dan lain sebagainya. Pada umumnya proses mengantri merupakan hal yang membosankan bagi masyarakat, karena selama ini sistem antrian yang digunakan mengharuskan customer melakukan pengambilan nomor antrian secara manual di loket ataupun mesin antrian. Setelah itu customer menunggu hingga nomor antriannya dipanggil dan menyelesaikan transaksinya. Hal ini tentunya akan menimbulkan ketidaknyamanan bagi customer seperti proses mengantri yang lama, ruang tunggu antrian yang kurang nyaman dan keterbatasan waktu customer yang hendak melakukan antrian di lain tempat. Selain itu, sering pula dijumpai pada beberapa tempat antrian, apabila terjadi gangguan teknis yang berpengaruh dengan sistem antriannya.

Dikarenakan sistem antrian merupakan suatu sistem pemrosesan data yang tidak boleh ditunda karena waktu sangat terbatas. Dan jika terjadi penundaan pengolahan data akan mengakibatkan ketidaknyamanan dan kerugian bagi customer maupun vendor. Selain membutuhkan respon yang cepat, customer juga membutuhkan suatu sistem antrian yang dapat mengakomodir beberapa vendor dalam satu sistem antrian terpadu. Yangmana hal ini akan memudahkan customer yang mempunyai keterbatasan waktu dengan tingkat mobilitas yang tinggi. Dengan adanya situasi tersebut, maka sebaiknya sebuah sistem antrian harus mempunyai server yang selalu aktif dan tidak bergantung pada kondisi-kondisi tertentu serta menghasilkan respon yang cepat dan tepat dalam batas waktu yang telah ditentukan (realtime).

Oleh karena itu, penulis mencoba mengembangkan teknologi berbasis mobile yang akan menggantikan sistem antrian yang ada, sehingga diharapkan dapat memberikan kepuasan kepada pelanggan dalam berbagai pelayanan publik. Selain itu, aplikasi ini diharapkan pula dapat mengorganisir sistem antrian berbagai pelayanan publik (multi vendor) sehingga lebih tertata, rapi dan mudah diakses. Aplikasi mobile ini dapat digunakan untuk berbagai pelayanan publik / vendor, yang mana aplikasi antrian ini merupakan aplikasi realtime dengan server sendiri menggunakan firebase tanpa harus berhubungan dengan server pribadi masing-masing vendor.

Sebelum menggunakan aplikasi ini, vendor diharuskan untuk melakukan registrasi atau pendaftaran melalui website. Vendor dapat memilih apakah sistem antriannya mengizinkan customer untuk memilih nomor antrian sesuai waktu yang diinginkan atau tidak. Kemudian customer yang telah memasang aplikasi ini dapat melihat data antrian pada masing-masing tempat yang menggunakan aplikasi ini, seperti nomor antrian sekarang dan sisa antrian. Customer juga dapat mengambil nomor antrian dengan jumlah maksimal satu nomor antrian untuk tiap jenis antrian. Customer dapat mengambil nomor antrian kembali jika nomor antrian tersebut telah dilakukan pemanggilan dan terkonfirmasi. Customer akan 
diberikan saran nomor antrian yang sesuai dengan perkiraan waktu tempuh customer dari lokasi saat ia mengambil nomor antrian menuju lokasi vendor

\section{Landasan Teori}

\subsection{Sistem Antrian}

Sistem antrian merupakan suatu himpunan pelanggan, petugas pelayanan (loket) serta suatu aturan yang mengatur kedatangan pelanggan dan pemrosesan masalah pelayanan antrian dimana dicirikan oleh lima buah komponen yaitu: pola kedatangan para pelanggan, pola pelayanan, jumlah pelayanan, kapasitas fasilitas untuk menampung para pelanggan dan aturan dalam mana para pelanggan dilayani [7].

Sistem antrian berfungsi untuk melakukan pengelolaan antrian dari suatu instansi/lembaga pelayanan publik, seperti bank, rumah sakit, kantor imigrasi, kantor pajak, BPJS, loket stasiun, dan lain sebagainya.

Ada tiga komponen dalam sistem antrian, yaitu:

- Kedatangan: merupakan proses input yang meliputi calling population atau sumber kedatangan, dan terjadinya merupakan suatu variabel yang bersifat acak.

- Pelayan: terdiri dari satu atau lebih pelayan maupun fasilitas pelayanan yang diberikan. Biasanya, fasilitas pelayanan tersebut disebut juga dengan saluran atau channel.

- Antri: merupakan faktor penting dari timbulnya antrian, yang terdiri dari sifat kedatangan dan proses layanan. Jika tidak ada antrian yang timbul, maka dapat dipastikan bahwa terdapat pelayanan yang menganggur atau fasilitas pelayanan yang berlebih.

\subsection{Pelayanan Publik}

Pelayanan merupakan suatu bentuk kegiatan pelayanan bagi masyarakat yang dilaksanakan oleh instansi pemerintahan baik di pusat, di daerah, BUMN, dan BUMD dalam bentuk barang maupun layanan jasa dalam rangka pemenuhan kebutuhan masyarakat sesuai peraturan perundang-undangan yang berlaku [5].

Berkaitan dengan pelayanan, terdapat dua istilah yang perlu diketahui, yaitu melayani dan pelayanan. Pengertian melayani adalah membantu menyiapkan ataupun mengurus apa yang diperlukan seseorang, sedangkan pelayanan merupakan suatu bentuk usaha melayani kebutuhan orang lain [2].

\subsection{Aplikasi Mobile}

Aplikasi mobile dapat diartikan sebagai sebuah produk dari sistem komputasi mobile, yaitu sistem komputasi yang dapat dengan mudah dipindahkan secara fisik dan yang komputasi kemampuan dapat digunakan saat mereka sedang dipindahkan. Contohnya adalah personal digital assistant (PDA), smartphone dan ponsel [1].

Berdasarkan jenisnya, Brian Fling (2009:70) membagi aplikasi mobile menjadi beberapa kelompok yaitu:

- $\quad$ Short Message Service (SMS)

Merupakan aplikasi mobile paling sederhana, dirancang untuk berkirim pesan dan berguna ketika terintegrasi dengan jenis aplikasi mobile lainnya.

- $\quad$ Mobile Websites (Situs Web Mobile)

Merupakan situs web yang dirancang khusus untuk perangkat mobile. Situs web mobile sering memiliki desain yang sederhana dan biasanya bersifat memberikan informasi.

- Mobile Web Application (Aplikasi Web

Aplikasi web mobile merupakan aplikasi mobile yang tidak perlu diinstal atau dikompilasi pada perangkat target. Menggunakan XHTML, CSS, dan JavaScript, aplikasi ini mampu memberikan pengguna pengalaman layaknya aplikasi native/asli.

- $\quad$ Native Application (Aplikasi Asli)

Merupakan aplikasi mobile yang harus diinstal pada perangkat target. Aplikasi ini dapat disebut aplikasi platform, karena aplikasi ini harus dikembangkan dan disusun untuk setiap platform mobile secara khusus.

\subsection{Firebase}

Firebase adalah penyedia layanan realtime database dan backend sebagai layanan. Suatu aplikasi yang memungkinkan pengembang membuat Application Programming Interface (API) untuk disinkronisasikan untuk client yang berbeda-beda dan disimpan pada cloud-nya Firebase. Firebase memiliki banyak library yang memungkinkan untuk mengintegrasikan layanan ini dengan Android, Ios, Javacript, Java, Objective-C dan Node.JS. Firebase Database juga bersifat bisa diakses lewat REST API. REST API tersebut menggunakan protokol Server-Sent Event dengan membuat koneksi Hypertext Transfer Protocol (HTTP) untuk menerima push notification dari server. Pengembang menggunakan REST API untuk post data yang selanjutnya Firebase client library yang sudah diterapkan pada aplikasi yang dibangun yang akan mengambil data secara realtime. 

yaitu:

Beberapa fitur yang terdapat pada Firebase

- Firebase Cloud Messaging: fitur ini merupakan platform yang digunakan untuk pesan dan notifikasi untuk android, ios, dan aplikasi web tanpa dikenakan biaya.

- Firebase Analytics: fitur ini adalah solusi pengukuran analisa aplikasi gratis yang memberikan wawasan tentang penggunaan aplikasi dan keterlibatan pengguna.

- Realtime Database: fitur ini merupakan database realtime dan backend sebagai layanan. Pengembangan dilengkapi dengan API untuk menyinkronkan data aplikasi diseluruh instansi/perusahaan dan data-data tersebut disimpan pada Firebase's cloud.

\subsection{Cloud Firestore}

Cloud Firestore adalah NoSQL, basis data berorientasi dokumen (document-oriented database). Tidak seperti database $S Q L$, pada Cloud Firestore tidak ada tabel atau baris. Sebagai gantinya, data yang akan disimpan dalam sebuah dokumen, yang diatur dan dikelompokkan ke dalam koleksi. Setiap dokumen berisi satu set pasangan key-value (disebut sebagai primary key pada database SQL). Cloud Firestore dioptimalkan untuk menyimpan koleksi yang besar dalam dokumen yang berukuran kecil.

\subsection{Angular}

Angular adalah platform yang dapat digunakan pengembang untuk membangun aplikasi yang aktif dan hidup, baik pada perangkat seluler/mobile, atau desktop. Angular merupakan sebuah framework javascript yang memungkinkan pembuatan reaktif Single Page Aplication (SPA). Single Page Aplication yaitu aplikasi yang berjalan hanya pada satu halaman, tidak membutuhkan reload page meskipun nampak di url berpindah halaman.

\section{Metodologi}

\subsection{Studi Literatur dan pengumpulan Data}

Studi literatur digunakan untuk mengumpulkan informasi yang dibutuhkan untuk pembuatan realtime mobile queue system multi vendor ini. Studi literatur dilakukan dengan pencarian referensireferensi yang terkait yaitu melalui internet. Informasi yang telah didapat diperoleh dari sumber baik yang berasal dari luar negeri maupun dalam negeri. Referensi yang digunakan sebagai sumber informasi dapat dilihat pada daftar pustaka di akhir laporan.

\subsection{Deskripsi Sistem}

Aplikasi ini dirancang untuk menggantikan sistem antrian yang sudah ada, dengan tujuan untuk dapat memberikan kepuasan kepada pelanggan dalam berbagai pelayanan publik. Aplikasi mobile ini dapat digunakan untuk berbagai pelayanan publik / vendor. Aplikasi antrian ini merupakan aplikasi realtime dengan server sendiri menggunakan firebase tanpa harus berhubungan dengan server pribadi masing-masing vendor.

Aplikasi ini memiliki dua aplikasi utama, yaitu aplikasi web based dan aplikasi android. Aplikasi web based digunakan untuk registrasi vendor oleh admin, dan pengelolaan sistem antrian di masingmasing vendor oleh admin vendor. Aplikasi web based dirancang menggunakan framework Angular 5 dan desain tampilan Boostsrap dan Material. Aplikasi android dirancang menggunakan Android Studio dengan minimal sistem operasi android adalah Ice Cream Sandwich.

\section{Implementasi}

Aplikasi Realtime Mobile Queue System Multi Vendor dibagi menjadi dua komponen, yaitu aplikasi berbasis website dan aplikasi berbasis android.

\subsection{Aplikasi Website}

Dalam aplikasi website terdapat 2 tipe user, yakni admin utama dan admin vendor. Admin utama bertugas untuk mengatur dan mengelola data-data vendor, sedangkan admin vendor bertugas untuk mengatur dan mengelola data-data loket masingmasing vendor.

\section{a. Tampilan Login Admin Utama}

Pada Gambar 1. Tampilan Login Admin Utama merupakan tampilan dari halaman login admin utama, yang mana hanya admin utama saja yang dapat mengakses fitur-fitur di dalamnya.

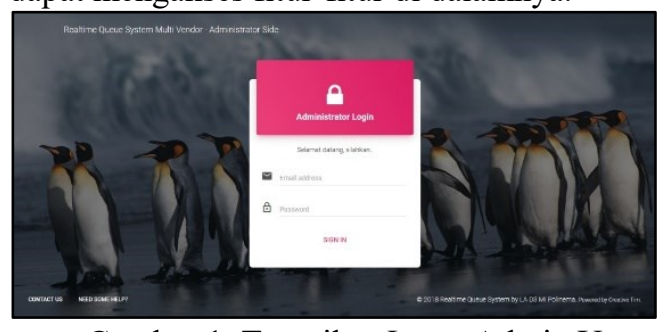

Gambar 1. Tampilan Login Admin Utama

\section{b. Tampilan Dashboard Admin Utama}

Pada Gambar 2. Tampilan Dashboard Admin Utama merupakan tampilan dari halaman dashboard admin utama. Dimana pada halaman ini merupakan halaman awal yang akan ditampilkan apabila proses login admin utama berhasil dan sukses.

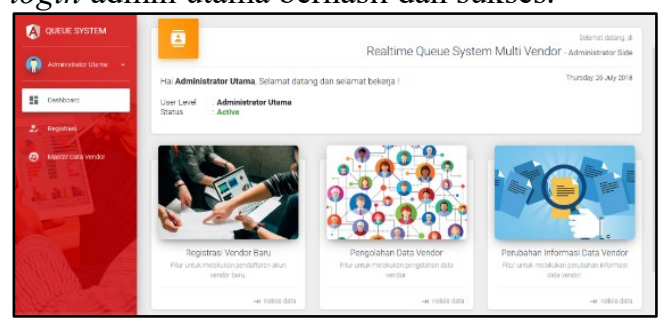

Gambar 2. Tampilan Dashboard Admin Utama

c. Tampilan Registrasi Vendor Baru 
Pada Gambar 3. Tampilan Registrasi Vendor Baru merupakan tampilan dari registrasi vendor baru, yang mana merupakan salah satu fitur yang berfungsi sebagai sarana bagi admin untuk melakukan pendaftaran vendor baru.

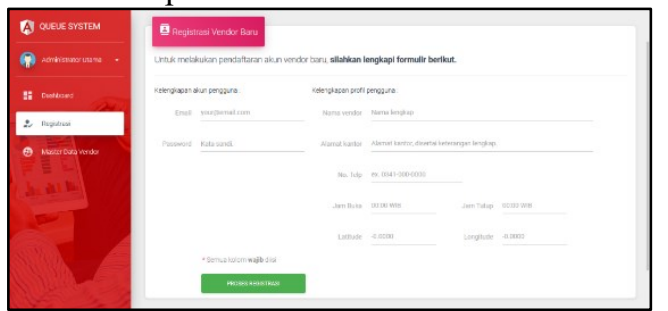

Gambar 3. Tampilan Registrasi Vendor Baru

d. Tampilan Master Data Vendor

Pada Gambar 4. Tampilan Master Data Vendor merupakan tampilan dari halaman master data vendor. Merupakan halaman dengan fitur yang memungkinkan admin dalam melakukan pengolahan data master vendor, seperti tambah data, mengubah informasi dan menghapus data.

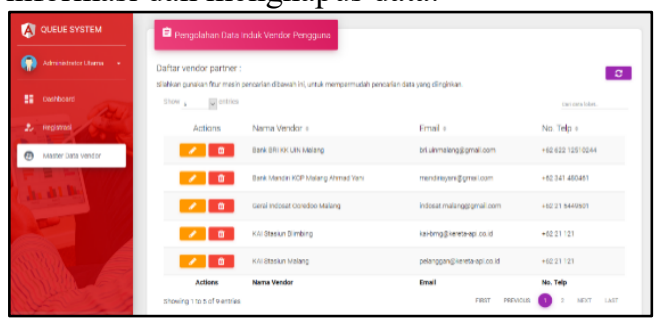

Gambar 4. Tampilan Master Data Vendor

e. Tampilan Edit Data Vendor

Pada Gambar 5. Tampilan Edit Data Vendor merupakan tampilan dari edit data vendor, yangmana merupakan salah satu fitur yang terdapat pada halaman master data vendor. Fitur ini berfungsi sebagai sarana bagi admin untuk melakukan perubahan informasi data vendor.

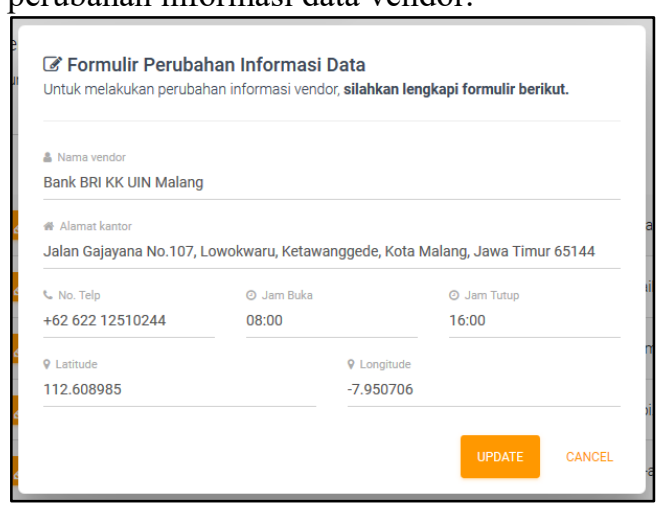

Gambar 5. Tampilan Edit Data Vendor

f. Tampilan Hapus Data Vendor

Pada Gambar 6. Tampilan Hapus Data Vendor merupakan tampilan dari hapus data vendor, yangmana merupakan salah satu fitur yang terdapat pada halaman master data vendor. Fitur ini berfungsi sebagai sarana bagi admin untuk menghapus data vendor.

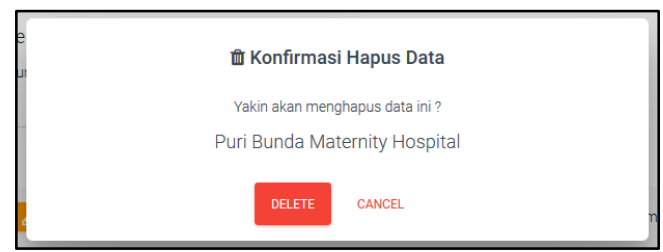

Gambar 6. Tampilan Hapus Data Vendor

g. Tampilan Login Admin Vendor

Pada Gambar 7. Tampilan Login Admin Vendor merupakan tampilan dari halaman login admin vendor, yangmana hanya user vendor terdaftar saja yang dapat mengakses fitur-fitur di dalamnya.

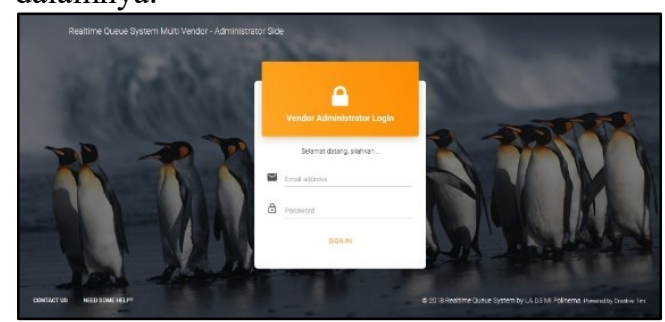

Gambar 7. Tampilan Login Admin Vendor

\section{h. Tampilan Dashboard Admin Vendor}

Pada Gambar 8. Tampilan Dashboard Admin Vendor merupakan tampilan dari halaman dashboard admin vendor, dimana pada halaman ini merupakan halaman awal yang akan ditampilkan apabila proses login berhasil dan sukses. Pada halaman ini akan ditampilkan beberapa informasi yang akan membantu user dalam melakukan akses terhadap aplikasi.

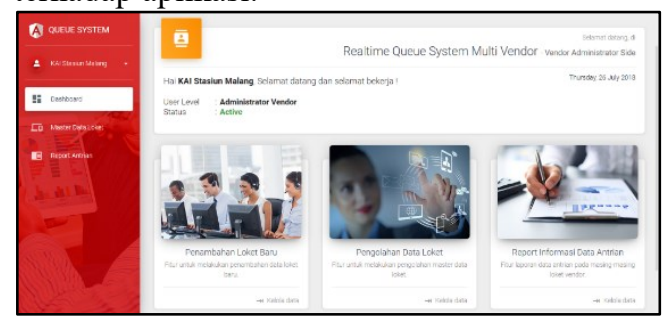

Gambar 8. Tampilan Dashboard Admin Vendor

i. Tampilan Master Data Loket

Pada Gambar 9. Tampilan Master Data Loket merupakan tampilan dari halaman master data loket. Merupakan halaman dengan fitur yang memungkinkan user dalam melakukan pengolahan data master loket, seperti tambah data loket, mengubah informasi loket dan menghapus data loket. 


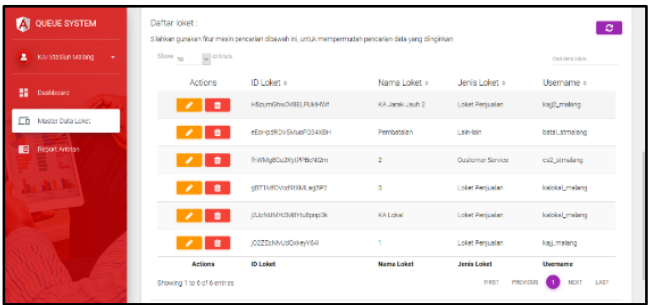

Gambar 9. Tampilan Master Data Loket

j. Tampilan Formulir Penambahan Loket Baru

Pada Gambar 10. Tampilan Formulir Penambahan Loket Baru merupakan tampilan dari formulir penambahan loket baru, yangmana merupakan salah satu fitur yang terdapat pada halaman master data loket. Fitur ini berfungsi sebagai sarana bagi user untuk melakukan penambahan data loket baru.

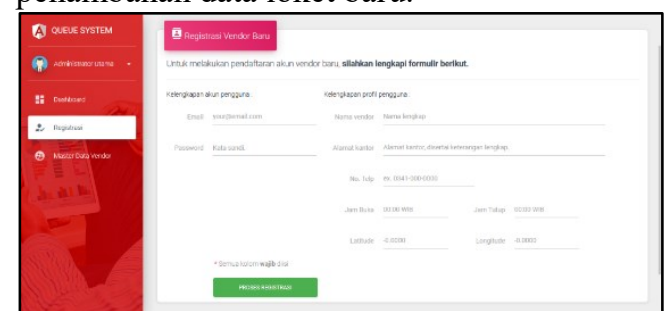

Gambar 10. Tampilan Formulir Penambahan Loket Baru

\section{k. Tampilan Edit Data Loket}

Pada Gambar 11. Tampilan Edit Data Loket merupakan tampilan dari edit data loket, yangmana merupakan salah satu fitur yang terdapat pada halaman master data loket. Fitur ini berfungsi sebagai sarana bagi user untuk melakukan perubahan informasi data loket.

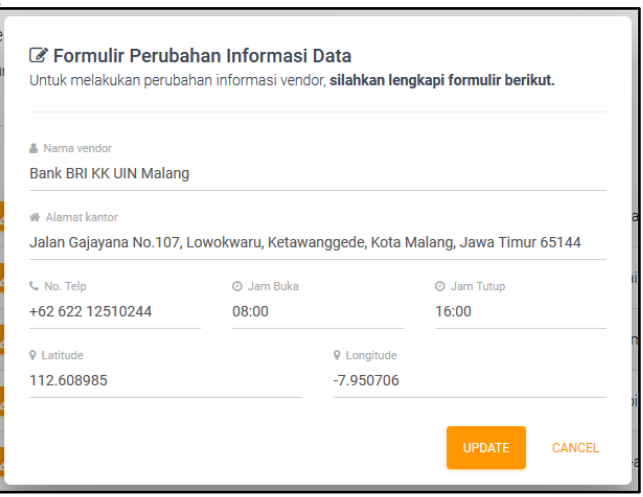

Gambar 11. Tampilan Edit Data Loket

\section{Tampilan Hapus Data Loket}

Pada Gambar 12. Tampilan Hapus Data Loket merupakan tampilan dari hapus data loket, yangmana merupakan salah satu fitur yang terdapat pada halaman master data loket. Fitur ini berfungsi sebagai sarana bagi user untuk menghapus data loket. Jika user menekan tombol Delete maka data loket yang dipilih akan terhapus, sedangkan jika user menekan tombol Cancel maka penghapusan data loket akan dibatalkan.

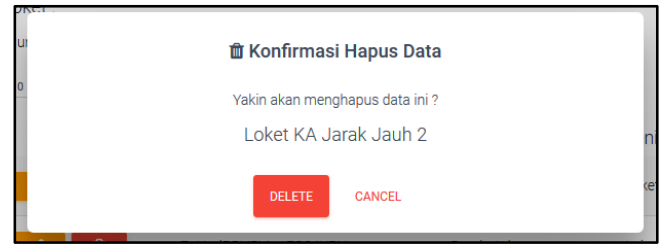

Gambar 12. Tampilan Hapus Data Loket

m. Tampilan Report Antrian

Pada Gambar 13. Tampilan Report Antrian merupakan tampilan dari halaman report antrian, dimana pada fitur yang berada pada halaman ini menampilkan informasi mengenai antrian yang sedang berjalan pada vendor.

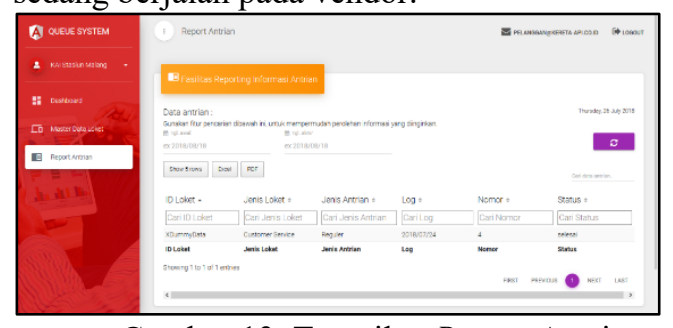

Gambar 13. Tampilan Report Antrian

\subsection{Aplikasi Android}

Dalam aplikasi android terdapat 2 tipe user, yakni loket dan customer. Loket bertugas untuk mengatur dan mengontrol jalannya antrian, sedangkan customer memiliki akses untuk melihat informasi jalannya antrian di berbagai tempat pelayanan publik dan mengambil nomor antrian.

a. Tampilan Login Loket

Pada Gambar 14. Tampilan Login Loket merupakan tampilan dari halaman login untuk petugas loket.

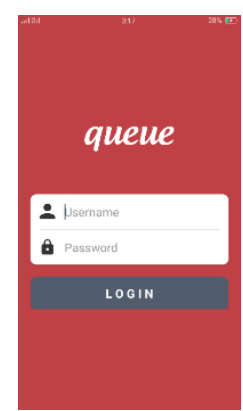

Gambar 14. Tampilan Login Loket

\section{b. Tampilan Antrian Loket}

Pada Gambar 15. Tampilan Antrian Loket merupakan tampilan dari halaman antrian pada loket. Pada halaman ini akan ditampilkan total dari sisa antrian dan nomor antrian yang akan dipanggil. Petugas loket dapat memanggil nomor antrian, dan melakukan konfirmasi apakah nomor antrian tersebut sudah hadir, atau belum hadir dan akan dilewati. Jika petugas loket menekan tombol panggil, maka aplikasi akan mengeluarkan panggilan suara nomor antrian. 


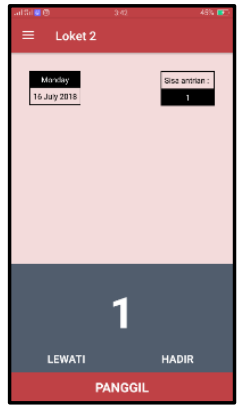

Gambar 15. Tampilan Antrian Loket

\section{c. Tampilan Menu Loket}

Pada Gambar 16. Tampilan Menu Loket merupakan tampilan dari menu loket. Pada menu ini terdapat fitur untuk petugas loket melakukan logout dan menutup loket. Jika petugas loket memilih menu Tutup Loket maka petugas loket akan keluar dari aplikasi dan status loket akan berubah menjadi tutup.

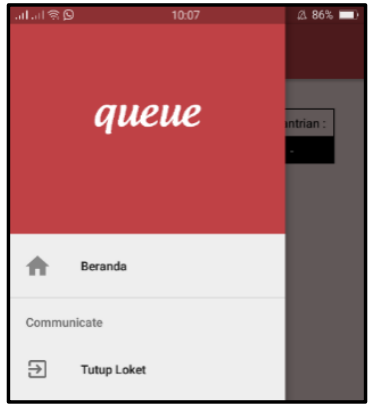

Gambar 16. Tampilan Menu Loket

\section{d. Tampilan Login Customer}

Pada Gambar 17. Tampilan Login Customer merupakan tampilan dari halaman login customer. Jika customer belum mendaftar maka dapat melakukan pendaftaran dengan menekan tombol Registrasi.

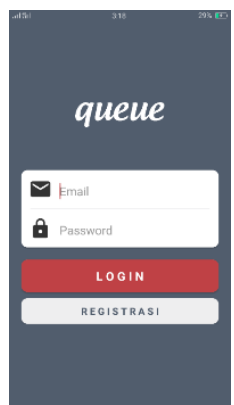

Gambar 17. Tampilan Login Customer

\section{e. Tampilan Antrian Customer}

Pada Gambar 18. Tampilan Antrian Customer merupakan tampilan dari halaman antrian customer. Pada halaman ini akan ditampilkan data antrian milik customer.

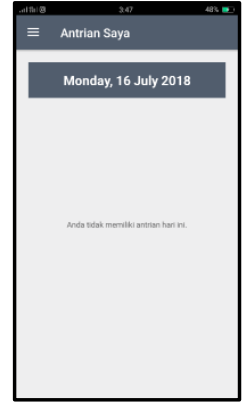

Gambar 18. Tampilan Antrian Customer

f. Tampilan Daftar Vendor

Pada Gambar 19. Tampilan Daftar Vendor merupakan tampilan dari halaman daftar vendor. Pada halaman ini menampilkan daftar dari berbagai pelayanan publik. Jika customer memilih salah satu pelayanan publik maka akan tampil halaman data loket yang tersedia pada pelayanan publik tersebut.

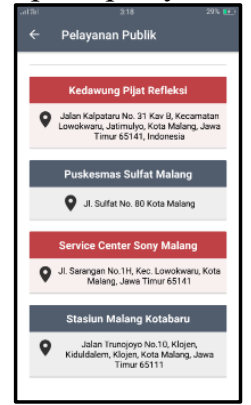

Gambar 19. Tampilan Daftar Vendor

\section{g. Tampilan Daftar Loket}

Pada Gambar 20. Tampilan Daftar Loket merupakan tampilan dari halaman daftar loket. Pada halaman ini menampilkan daftar loket dari pelayanan publik. Jika customer memilih salah satu loket maka akan tampil halaman antrian yang menampilkan data antrian pada jenis loket yang telah dipilih.

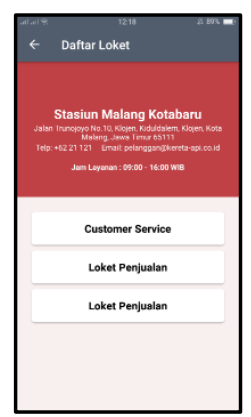

Gambar 20. Tampilan Daftar Loket

\section{h. Tampilan Antrian Jam}

Pada Gambar 21. Tampilan Antrian Jam merupakan tampilan dari halaman antrian berdasar jam. Pada halaman ini menampilkan daftar antrian yang dapat diambil oleh customer berdasar jam yang diinginkan. Nomor antrian yang dapat diambil oleh customer adalah nomor antrian berwarna abu-abu. Untuk nomor antrian berwarna merah tidak dapat 
diambil karena nomor antrian tersebut sudah diambil oleh customer yang lain.

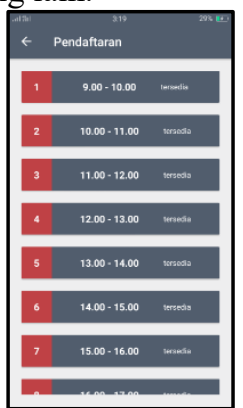

Gambar 21. Tampilan Antrian Jam

\section{i. Tampilan Antrian Nomor}

Pada Gambar 22. Tampilan Antrian Nomor merupakan tampilan dari halaman antrian berdasar nomor yang menampilkan nomor antrian yang dapat diambil, nomor antrian yang sedang dilayani, dan total dari sisa antrian. Jika customer menekan tombol LIHAT SARAN maka akan menuju halaman saran antrian.

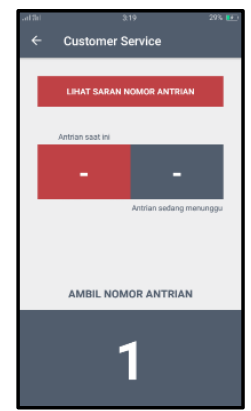

Gambar 22. Tampilan Antrian Nomor

\section{j. Tampilan Saran Antrian}

Pada Gambar 23. Tampilan Saran Antrian merupakan tampilan dari halaman saran antrian. Pada halaman ini menampilkan saran beberapa nomor antrian berdasar perkiraan waktu tempuh customer menuju lokasi pelayanan publik.

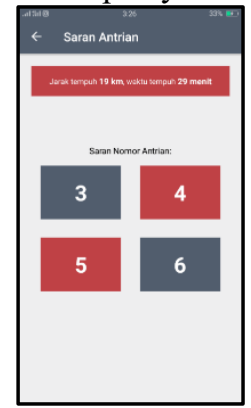

Gambar 23. Halaman Saran Antrian

\section{Pengujian}

Uji coba dilakukan untuk memastikan bahwa setiap fungsi pada aplikasi telah berjalan sesuai dengan tugasnya. Pengujian pada aplikasi menggunakan metode blackbox. Pengujian dengan menggunakan metode blackbox, artinya pengujian aplikasi dilakukan berdasarkan fungsi dari aplikasi tersebut. Tujuan dari pengujian untuk menemukan kesalahan fungsi pada aplikasi.

Tabel 1. Black Box Pengujian Aplikasi Website

\begin{tabular}{|c|c|c|c|}
\hline No & Fitur & Pengujian & Hasil \\
\hline 1 & $\begin{array}{l}\text { Fitur login } \\
\text { sistem }\end{array}$ & $\begin{array}{l}\text { Menampilkan } \\
\text { halaman dashboard, } \\
\text { apabila login berhasil }\end{array}$ & Berhasil \\
\hline 2 & $\begin{array}{l}\text { Fitur } \\
\text { registrasi } \\
\text { vendor } \\
\text { baru }\end{array}$ & $\begin{array}{l}\text { Menyimpan data } \\
\text { vendor baru ke dalam } \\
\text { database }\end{array}$ & Berhasil \\
\hline 3 & $\begin{array}{l}\text { Fitur edit } \\
\text { data } \\
\text { vendor }\end{array}$ & $\begin{array}{l}\text { Perubahan data dapat } \\
\text { tersimpan pada } \\
\text { database }\end{array}$ & Berhasil \\
\hline 4 & $\begin{array}{l}\text { Fitur delete } \\
\text { data } \\
\text { vendor }\end{array}$ & $\begin{array}{l}\text { Menghapus data dari } \\
\text { sistem dan database }\end{array}$ & Berhasil \\
\hline 5 & $\begin{array}{l}\text { Fitur } \\
\text { tambah } \\
\text { data loket }\end{array}$ & $\begin{array}{l}\text { Menampilkan form } \\
\text { tambah data loket }\end{array}$ & Berhasil \\
\hline 6 & $\begin{array}{l}\text { Fitur edit } \\
\text { data loket }\end{array}$ & $\begin{array}{l}\text { Perubahan data dapat } \\
\text { tersimpan } \\
\text { database }\end{array}$ & Berhasil \\
\hline 7 & $\begin{array}{l}\text { Fitur delete } \\
\text { data loket }\end{array}$ & $\begin{array}{l}\text { Menghapus data dari } \\
\text { sistem dan database }\end{array}$ & Berhasil \\
\hline 8 & $\begin{array}{l}\text { Fitur lihat } \\
\text { data } \\
\text { antrian }\end{array}$ & $\begin{array}{ll}\text { Menampilkan } & \\
\text { halaman } & \text { report } \\
\text { antrian } & \\
\end{array}$ & Berhasil \\
\hline 9 & $\begin{array}{l}\text { Fitur } \\
\text { logout } \\
\text { sistem }\end{array}$ & $\begin{array}{l}\text { Keluar dari sistem } \\
\text { dan menampilkan } \\
\text { halaman login }\end{array}$ & Berhasil \\
\hline
\end{tabular}

Tabel 2. Black Box Pengujian Aplikasi Android

\begin{tabular}{|l|l|l|c|}
\hline No & \multicolumn{1}{|c|}{ Fitur } & \multicolumn{1}{|c|}{ Pengujian } & Hasil \\
\hline 1 & $\begin{array}{l}\text { Fitur login } \\
\text { loket }\end{array}$ & $\begin{array}{l}\text { Masuk ke halaman } \\
\text { antrian loket dan status } \\
\text { loket menjadi "buka" }\end{array}$ & Berhasil \\
\hline 2 & $\begin{array}{l}\text { Fitur } \\
\text { konfirmasi } \\
\text { kehadiran } \\
\text { customer }\end{array}$ & $\begin{array}{l}\text { Memanggil nomor } \\
\text { antrian dan melakukan } \\
\text { konfirmasi apakah } \\
\text { customer hadir atau } \\
\text { dilewati }\end{array}$ & Berhasil \\
\hline 3 & $\begin{array}{l}\text { Fitur tutup } \\
\text { loket }\end{array}$ & $\begin{array}{l}\text { Menutup loket dan } \\
\text { keluar dari akun loket }\end{array}$ & Berhasil \\
\hline 4 & $\begin{array}{l}\text { Fitur login } \\
\text { cutomer }\end{array}$ & $\begin{array}{l}\text { Masuk ke halaman } \\
\text { antrian customer }\end{array}$ & Berhasil \\
\hline 5 & $\begin{array}{l}\text { Fitur } \\
\text { registrasi } \\
\text { customer }\end{array}$ & $\begin{array}{l}\text { Melakukan pendaftaran } \\
\text { akun untuk login }\end{array}$ & Berhasil \\
\hline 6 & $\begin{array}{l}\text { Fitur } \\
\text { antrian } \\
\text { customer }\end{array}$ & $\begin{array}{l}\text { Menampilkan kartu } \\
\text { antrian jika customer } \\
\text { memiliki antrian aktif }\end{array}$ & Berhasil \\
\hline 7 & $\begin{array}{l}\text { Fitur } \\
\text { konfirmasi } \\
\text { kehadiran }\end{array}$ & $\begin{array}{l}\text { Melakukan konfirmasi } \\
\text { ketika customer sudah } \\
\text { tiba di lokasi pelayanan } \\
\text { publik Berhasil }\end{array}$ & \\
\hline
\end{tabular}




\begin{tabular}{|c|l|l|l|}
\hline 8 & $\begin{array}{l}\text { Fitur } \\
\text { batalkan } \\
\text { antrian }\end{array}$ & $\begin{array}{l}\text { Membatalkan nomor } \\
\text { antrian yang dimiliki }\end{array}$ & Berhasil \\
\hline 9 & $\begin{array}{l}\text { Fitur } \\
\text { daftar } \\
\text { vendor }\end{array}$ & $\begin{array}{l}\text { Melihat daftar } \\
\text { pelayanan publik }\end{array}$ & Berhasil \\
\hline 10 & $\begin{array}{l}\text { Fitur } \\
\text { daftar } \\
\text { loket }\end{array}$ & $\begin{array}{l}\text { Melihat daftar loket dari } \\
\text { pelayanan publik yang } \\
\text { dipilih }\end{array}$ & Berhasil \\
\hline 11 & $\begin{array}{l}\text { Fitur } \\
\text { antrian } \\
\text { berdasar } \\
\text { jam }\end{array}$ & $\begin{array}{l}\text { Melihat daftar nomor } \\
\text { antrian berdasar jam }\end{array}$ & Berhasil \\
\hline 12 & $\begin{array}{l}\text { Fitur } \\
\text { antrian } \\
\text { berdasar } \\
\text { nomor }\end{array}$ & $\begin{array}{l}\text { Melihat daftar antrian } \\
\text { berdasar nomor }\end{array}$ & Berhasil \\
\hline 13 & $\begin{array}{l}\text { Fitur saran } \\
\text { antrian }\end{array}$ & $\begin{array}{l}\text { Melihat saran nomor } \\
\text { antrian berdasar } \\
\text { perkiraan waktu tempuh } \\
\text { customer menuju lokasi } \\
\text { pelayanan publik }\end{array}$ & Berhasil \\
\hline 15 & $\begin{array}{l}\text { Fitur } \\
\text { logout } \\
\text { amtrian }\end{array}$ & $\begin{array}{l}\text { Kengambil nomor } \\
\text { antrian }\end{array}$ & Berhasil \\
customer & Berhasil \\
\hline 14 & $\begin{array}{l}\text { Fitur } \\
\text { ambil akun }\end{array}$ & \\
\hline
\end{tabular}

\section{Kesimpulan dan Saran}

\subsection{Kesimpulan}

Berdasarkan hasil ujicoba Aplikasi Realtime Mobile Queue System Multi Vendor, dapat ditarik kesimpulan bahwa aplikasi ini dapat menghasilkan sebuah sistem antrian yang memudahkan customer dalam mencari dan mengambil nomor antrian di berbagai pelayanan publik, dan mempersingkat waktu tunggu customer di lokasi pelayanan publik sehingga meminimalisir terjadinya antrian yang panjang. Aplikasi ini juga mudah digunakan, dengan fitur pengambilan nomor antrian di beberapa tempat yang berbeda tanpa harus datang ke tempat penyedia antrian terlebih dahulu.

Selain itu, aplikasi ini juga dapat meningkatkan kualitas pelayanan vendor, dengan menerapkan sebuah sistem antrian baru yang memiliki beberapa kelebihan seperti penyediaan informasi antrian yang akurat, kemudahan dalam pengambilan nomor antrian dan kemampuan aplikasi dalam memfasilitasi customer yang hendak mengambil nomor antrian secara custom sesuai dengan waktu yang dibutuhkan. Sehingga dengan meningkatnya kualitas dari fasilitas dan pelayanan vendor, maka akan meningkatkan pula kepuasan dari customer.

\subsection{Saran}

Terdapat beberapa saran yang perlu disampaikan dengan harapan menjadi suatu masukan untuk pengembangan aplikasi ini:

- Penambahan fitur pencarian data pelayanan publik sehingga proses pencarian data pelayanan publik pada aplikasi android lebih memudahkan pengguna.

- Penggunaan fitur cetak data antrian pada aplikasi website admin vendor yang dapat membantu pihak vendor dalam memperoleh informasi seputar pelayanan antrian yang telah berjalan.

1. Daftar Pustaka

[1] B'Far, Reza. 2005. Mobile Computing Principle. New York: Cambridge Univesity Press.

[2] Departemen Pendidikan Dan Kebudayaan. 1995. Kamus Besar Bahasa Indonesia. Jakarta: Balai Pustaka.

[3] Firebase. 2015. "Meet Firebase". URL: https://firebase.google.com/ (diakses pada: 12/01/2017).

[4] Fling, Brian. 2009. Mobile Design and Development, 1st edition. United State of America: O’Reilly Media, Inc.

[5] Keputusan Menpan no. 81 tahun 1993 tentang Penyelengaraan Pelayanan Publik.

[6] Lestari, Yayuk Diah. 2016. Aplikasi Android untuk Pendaftaran Poliklinik Anak, Gigi, dan Mata di RSUD Dokter R. Soetijono Blora. Semarang: Tanpa Penerbit.

[7] Lumba, Ester. 2015. Sistem Antrian Untuk Mempermudah Pelayanan Pasien Rawat Jalan Pada Puskesmas XYZ. Jakarta Timur: Tanpa Penerbit.

[8] Rief, Jacob. 2018. django-angular Documentation Release 2.0.3. Tanpa Kota: Tanpa Penerbit.

[9] Subagyo, Pangestu, dkk. 2000. "Dasar Dasar Operations Research”. Yogyakarta: BPFE. 